\title{
Influence of macrohabitat preferences on the distribution of European brook and river lampreys: Implications for conservation and management
}

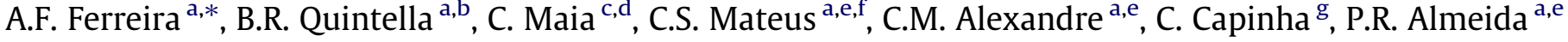 \\ ${ }^{a}$ Center of Oceanography, Faculty of Sciences of the University of Lisbon, Campo Grande, 1749-016 Lisbon, Portugal \\ ${ }^{\mathrm{b}}$ Department of Animal Biology, Faculty of Sciences of the University of Lisbon, Campo Grande, 1749-016 Lisbon, Portugal \\ c Planeta Vivo, Center of Environmental Investigation, Avenida da Liberdade, 4450-718 Leça da Palmeira, Portugal \\ ${ }^{\mathrm{d}}$ Eco-ethology Research Unit, ISPA, Rua Jardim do Tabaco, 1149-041 Lisbon, Portugal \\ e Department of Biology, School of Science and Technology, University of Évora, Largo dos Colegiais 2, 7000 Évora, Portugal \\ ${ }^{\mathrm{f}}$ National Museum of Natural History \& Center for Environmental Biology, University of Lisbon, Rua da Escola Politécnica 58, 1250-102 Lisbon, Portugal \\ ${ }^{\mathrm{g}}$ Centre for Geographic Studies, University of Lisbon, Alameda da Universidade, 1600-214 Lisbon, Portugal
}

\section{A R T I C L E I N F O}

\section{Article history:}

Received 26 June 2012

Received in revised form 16 October 2012

Accepted 13 November 2012

Available online 23 January 2013

Keywords:

Predictive model

Lampetra planeri

L. fluviatilis

Boosted Regression Trees

Threatened species

Portugal

\begin{abstract}
A B S T R A C T
The European river lamprey, Lampetra fluviatilis (L.), and the European brook lamprey, Lampetra planeri (Bloch, 1784), are considered highly threatened in Portugal. However, the lack of information about the ecology and distribution of these species poses difficulties to the identification of concrete actions directed to their conservation. A total of 401 sampling sites, randomly distributed throughout the entire Portuguese mainland territory were selected, and Lampetra sp. ammocoetes presence or absence checked with electrofishing. These data, together with 11 macrohabitat predictors, were analyzed using Boosted Regression Trees (BRTs). The BRT models consistently identified five environmental variables as the most important for predicting the distribution of European brook and river lamprey ammocoetes: altitude, distance to coast, sand, maximum temperature of the warmest month and precipitation of the driest month. The relationships of these variables with the species probability of occurrence suggest that lampreys occur in low altitude river stretches $(<170 \mathrm{~m})$, relatively close to the coast $(<150 \mathrm{~km})$ and with a sandy substrate ( $>70 \%$ sand). In addition, intermediate values of temperature and precipitation were also found to have a positive correlation with the species occurrence. A map with the probability of occurrence of Lampetra sp. in Portugal was generated and stretches of rivers were delimited with different conservation priorities. Rivers classified with the highest level of conservation priority were considered to be proposed as Special Areas of Conservation, under the Natura 2000 Networking Programme.
\end{abstract}

(c) 2012 Elsevier Ltd. All rights reserved.

\section{Introduction}

There are three species of lampreys in Portugal: the sea lamprey (Petromyzon marinus L.), the European river lamprey (Lampetra fluviatilis L.) and the European brook lamprey (Lampetra planeri Bloch, 1784) (Baldaque da Silva, 1891). While P. marinus and L. fluviatilis are parasitic and anadromous, $L$. planeri is non-parasitic and resident, inhabiting strictly freshwater environments (Hardisty, 1986a, 1986b, 1986c). Although being considered of "Least Concern" in Europe (IUCN, 2010), the genus Lampetra is considered highly threatened on the Iberian Peninsula, the southern limit of its distribution (Cabral et al., 2005; Doadrio, 2001; Mateus et al., 2012). In Spain, the European river lamprey is considered "Region-

\footnotetext{
* Corresponding author. Tel.: +351 2175009 97; fax: +35121750 0009 .

E-mail address: afferreira@fc.ul.pt (A.F. Ferreira).
}

ally Extinct" and the European brook lamprey is considered "Critically Endangered" (Doadrio, 2001). In Portugal, both species are classified as "Critically Endangered" mainly due to the high population fragmentation, declining number of subpopulations and habitat degradation (Cabral et al., 2005). The high population fragmentation of Lampetra sp. populations in Portugal is mainly caused by the construction of obstacles to migration (dams, weirs and other man-made barriers) that prevent the anadromous species from reaching the spawning grounds and the gene flow between some resident populations within the same watershed. Habitat degradation may also limit the area available for these species and be responsible for the isolation of some subpopulation nucleus within the same watershed. The main causes of the habitat degradation are water pollution, dredging and habitat destruction through channel and bank regulation (Mateus et al., 2012).

During the larval and metamorphosis stages (where lampreys are known as ammocoetes and transformers, respectively), the 
morphological distinction of lampreys is often difficult (Hardisty and Potter, 1971). In addition, ammocoetes of all three species may sometimes be found at the same sites (Hardisty, 1979), which makes even more difficult the distinction between them. It is possible to distinguish between $P$. marinus and Lampetra sp. ammocoetes by the presence of different patterns of pigmentation in the head and tail (Potter and Osborne, 1975). However, in the larval and transformer phases, the two Lampetra species are morphologically similar, and neither taxonomic (Hardisty and Potter, 1971; Zanandrea, 1959) nor genetic criteria (Espanhol et al., 2007; Schreiber and Engelhorn, 1998) can separate them in the present state of knowledge. In fact, the taxonomic status of river and brook lampreys is still under debate (Blank et al., 2008; Espanhol et al., 2007; Schreiber and Engelhorn, 1998). The hypothesis of the existence of a single species with two distinct ecotypes that evolve according to the environmental pressures has been proposed by several authors (e.g. Docker, 2009; Eneqvist, 1937; Espanhol et al., 2007).

L. planeri and $L$. fluviatilis are confined to European watersheds, occurring from Norway in the north to the Iberian Peninsula in the south (Hubbs and Potter, 1971; Mateus et al., 2012). Unlike in the rest of its geographic range, in the Iberian Peninsula L. fluviatilis and $L$. planeri have distinct distributions. In Spain, L. fluviatilis is extinct and only two populations of $L$. planeri are known, one of which only recently described (Mateus et al., 2011a; Perea et al., 2011). In Portugal, while L. fluviatilis is only found in the Tejo river basin, L. planeri has a wider distribution (Almaça and CollaresPereira, 1988; Espanhol et al., 2007; Mateus et al., 2012). Considering the restricted distribution of $L$. fluviatilis in Portugal (already extinct in Spain), as well as the highly fragmented Portuguese populations of $L$. planeri (with restricted distribution in Spain), in addiction to all the threats that both species are subject (see next paragraph), it is of great importance the effective conservation of the Portuguese populations of this genus, with the risk of, otherwise, losing the southern populations of both species. In addition, genetic diversity attained for the Iberian glacial refugia is higher than that found for the rest of the distribution area of both species (Espanhol et al., 2007; Mateus et al., 2011b), thus, failure in conservation strategies would result in the loss of genetic diversity and unique evolutionary lineages of the Iberian Peninsula.

The conservation of both Lampetra species in the Iberian Peninsula is dependent on the effective habitat preservation and rehabilitation measures. However, the lack of general information concerning these species, particularly the ones related to habitat preferences and the identification of the environmental conditions responsible for their distribution, has been delaying the effective designation of special sites for the genus protection under the scope of the Natura 2000 Networking Program. According to the Habitats Directive (92/43/EEC), European Union member states are required to identify Special Areas of Conservation (SAC) for species considered to be under threat and listed under Annex II of this Directive. The designation and protection of these habitats is important for the preservation of species more susceptible to the numerous anthropogenic threats (Primack, 1995). The identification of the environmental factors that constrain the presence of Lampetra sp. is an important tool in the selection of suitable sites for designation (Goodwin et al., 2008). This information is particularly important to predict species distribution.

The main objective of this study was to gather the necessary information to properly designate SAC for the genus Lampetra in Portugal. To achieve this objective we first performed a comprehensive sampling survey to identify presence or absence of ammocoetes belonging to the genus Lampetra throughout Portuguese watersheds. Secondly, the presence/absence information was statistically analyzed, together with several environmental predictors selected a priori, generating a model that tries to explain the distribution of Lampetra sp. in Portugal. Using the distribution model output, a map of probability of occurrence of Lampetra sp. for the entire Portuguese territory was generated. Finally, priority conservation criteria were defined to classify watersheds according to their importance to Lampetra species. Water stretches included in the highest priority conservation level were set to be proposed as SAC under the European Natura 2000 ecological network of protected areas.

\section{Materials and methods}

\subsection{Study area and sampling}

This study was performed in mainland Portugal, south-western Europe. It comprises an area of approximately $89060 \mathrm{~km}^{2}$ with a relatively high climatic, geomorphologic and hydrologic heterogeneity. Portuguese climate is characterized by wet winters and dry summers that are temperate in almost the entire west coast, and hot on the majority of the southern central plateau region (ICA, 2011). Current environmental conditions produce several types of watercourses, ranging from perennial streams with continuous flow in the northern region to typical Mediterranean temporary streams with clearly marked cycles of floods and droughts in the south (Gasith and Resh, 1999).

The Lampetra sp. presence and absence database included data from two main sources: the field campaigns developed in 2002 for the Portuguese Red List of Threatened Vertebrates (Cabral et al., 2005), and the National Conservation Plan for Brook and River lampreys (Almeida et al., 2011), collected in 2009 and 2010. The same sampling procedure was used for both field surveys to maximize the probability of ammocoetes capture and reduce sampling costs due to the large size of the study area. Prior to the selection of sampling sites, a number of preliminary sampling stations were marked, proportionally to the total drainage area of each river basin with a minimum of one sampling station per $17.5 \times 17.5 \mathrm{~km}$ squares of catchment area. However, during the field surveys, if the sampling sites did not present the minimum conditions to sustain a population of ammocoetes (i.e. presence of sandy substrate), these points were whenever possible randomly replaced by others located in the same grid. There were effectively sampled 401 stations. Ammocoetes were collected by electro fishing (Hans Grassl ELT 60 II-HI $500 \mathrm{~V}$-DC) from May to September. The stretch of the river sampled was 20 times the average width of the flooded area of the river, for rivers up to $30 \mathrm{~m}$ wide, and 10 times the average width of the river, for rivers more than $30 \mathrm{~m}$ wide. Geographic coordinates of sampling stations were recorded with a handheld GPS (Magellan SportTrak).

\subsection{Environmental predictors}

The environmental variables used for modeling the distribution of Lampetra sp. were selected by their a priori potential relevance to the studied lamprey species and conditioned by the availability of high quality data for the entire study area. Seventeen environmental variables were selected within the following parameters typology: geomorphology, climate, environmental stressors and hydrology (Table 1). This information was derived from previous databases and Geographic Information System (GIS) (ESRI, 2009).

The variables used in the analysis belonging to the geomorphology features were: altitude, river slope, distance to coast, and the type of substrate through the percentage of silt and sand in the soil. Altitude (altitude) was obtained from the Shuttle Radar Topography Mission (resolution of $1 \mathrm{~km}^{2}$; SRTM, 2010). Elevation is an indicator of local topographically driven variation in river flux, which in turn influences the development of local habitat differentiation (Leathwick et al., 2008), such as water velocity, depth and substrate coarseness (Lassalle et al., 2008). The variable slope 
Table 1

Environmental variables used in the analysis and gathered through GIS databases.

\begin{tabular}{|c|c|c|}
\hline Variables & Code & Range \\
\hline \multicolumn{3}{|l|}{ Geomorphology } \\
\hline Altitude $(\mathrm{m})$ & altitude & $0-1991$ \\
\hline Slope $\left(^{\circ}\right)$ & slope & $0-53.788$ \\
\hline Distance to coast (m) & dist_co & $0-357679$ \\
\hline Silt $(\%)$ & silt & $3.6-20.3$ \\
\hline Sand (\%) & sand & $19.1-85.9$ \\
\hline \multicolumn{3}{|l|}{ Climate } \\
\hline Annual mean temperature $\left({ }^{\circ} \mathrm{C}\right)$ & meantemp & $5.9-17.6$ \\
\hline Max temperature of warmest month $\left({ }^{\circ} \mathrm{C}\right)$ & maxtemp & $19.4-34.0$ \\
\hline Annual precipitation ( $\mathrm{mm})$ & preca & $458-1798$ \\
\hline Precipitation of driest month (mm) & precdrie & $0-37$ \\
\hline \multicolumn{3}{|l|}{ Environmental stressors } \\
\hline Artificial surfaces (no. of cells) & use_art & $0-6083$ \\
\hline Agricultural areas (no. of cells) & use_agri & $0-218889$ \\
\hline Forest and semi natural areas (no. of cells) & use_nat & $0-161346$ \\
\hline Population $\left(\mathrm{n} / \mathrm{km}^{2}\right)$ & populat & $0-19303$ \\
\hline \multicolumn{3}{|l|}{ Hydrology } \\
\hline Flow accumulation (no. of cells) & fcum & $0-9764683$ \\
\hline Flow-weight with rainfall (no. of cells) & frain & $0-245475437$ \\
\hline WTI & $w t i$ & $0-20.07$ \\
\hline SPI & spi & $-8.2 \times 10^{9}$ to $2.4 \times 10^{11}$ \\
\hline
\end{tabular}

(slope) was also included in the analysis since it is generally positively correlated with river velocity and substrate coarseness. Distance to coast (dist_co) was included in the analysis since it reflects the variation of the physical characteristics of the rivers from the headwaters to downstream extent (Vannote et al., 1980). Both slope and distance to coast were calculated using the SRTM Digital Elevation Model in ArcGIS (ESRI, 2009). The substrate composition is recognized as one of the most important factors limiting the distribution of ammocoetes (e.g. Almeida and Quintella, 2002; Beamish and Jebbink, 1994; Kainua and Valtonen, 1980; Malmqvist, 1980; Morman et al., 1980). In order to evaluate the importance of this parameter at a macrospatial scale, two substrate related variables were used. The data were derived from the Harmonized World Soil Database $\left(1 \mathrm{~km}^{2} /\right.$ resolution; FAO/IIASA/ISRIC/ISSCAS/ JRC, 2009). They represent the percentage of silt (silt, between 0.002 and $0.063 \mathrm{~mm}$ ) and sand (sand, between 0.063 and $2 \mathrm{~mm}$ ) that composes the soil.

Parameters that reflect the river hydrology were also inputted in the model. Variation in flow has been identified as an important determinant of the biological character of rivers and streams (Poff, 1997), and can successfully predict a range of biological features, including the distributions of individual fish species (Jowett, 1990; Poff et al., 1997; Richter et al., 2003) and community structure of fish (Poff and Allan, 1995). Because of the temporary regime of the majority of Portuguese rivers, flow is an important variable in the distribution of freshwater fishes. Flow was estimated using two flow accumulation functions in ArcGIS and two flow indexes in Saga (SAGA, 2010). The flow accumulation (fcum) function corresponds simply to the total area that drains to each location, while flow (frain) was calculated using the same flow accumulation function but weighted by the mean annual precipitation (Hijmans et al., 2005). The Saga Wetness Index (wti; Böhner et al., 2002) and the Stream Power Index (spi; Moore et al., 1988) are measures of the wetness and the flow erosion power of the river, respectively.

Four climate variables were also tested: annual mean temperature (meantemp), maximum temperature of the warmest month (maxtemp), annual precipitation (preca) and precipitation of the driest month (precdrie). All this information was derived from WorldClim database (Hijmans et al., 2005) at a $1 \mathrm{~km}^{2}$ cell resolution. Water temperature has been identified as an important habitat factor for many freshwater organisms (e.g. Richardson et al., 1994 ) including lampreys (Hardisty and Potter, 1971). Air temper- ature is a good proxy for water temperature. Indeed, a linear relationship exists between air temperature above $0^{\circ} \mathrm{C}$ and water temperature (Erickson and Stefan, 2000). Precipitation can be an indicator of the amount of water received in a basin and the importance of this variable is also related with the water availability in the study area. The maximum temperature of the warmest month and the precipitation of the driest month, two variables that represent extreme periodic climatic events may be particularly useful predictors to explain the distribution of species habiting the southern limit of their distribution area and, consequently, were selected to enter the analysis.

Pollution is pointed as one of the major threats contributing to the decline of lampreys (Almeida et al., 2002; Maitland, 2003), and presumably entire populations disappeared from rivers that became polluted (Mateus et al., 2012). Because there is no extensive base data concerning the aquatic pollution in Portuguese rivers and assuming that water quality is associated with the land uses drained (e.g. Kroll et al., 2009), we tried to approximate this information using data of Corine Land Cover 2000 (CLC; EEA, 2010; $100 \mathrm{~m}^{2}$ of resolution). To do this, we first divided the CLC information into three types of land uses: (1) artificial surfaces (use_art), (2) agricultural uses (use_agri) and (3) forest and semi-natural areas (use_nat). In each type of land use, the uses of the group's one, two and three of the CLC database were included. The spatial extent of each of the three above mentioned land uses flowing into any point of the river network was then assessed through a weighted flow accumulation model in ArcGIS (ESRI, 2009). In order to obtain estimates of spatial extent, weights in each cell corresponded simply to the presence (1) or absence (0) of that particular land use. Demographic information (total population - populat) was also gathered, data derived from LandScan (LandScan, 2010; $1 \mathrm{~km}^{2}$ of resolution), and used as indicative of organic pollution contamination level from domestic effluents.

\subsection{Statistical modeling}

For each sampled site the value of each predictor was obtained and an analysis of Pearson coefficients was applied. Correlations between variables higher than 0.8 , in absolute number, were signaled and only one of those variables were selected for inclusion in the statistical procedure (c.f. Snelder and Lamouroux, 2010), to avoid the inclusion of redundant variables in the models. 
Boosted Regression Trees (BRTs) analysis was used (Elith et al., 2008; Friedman, 2001, 2002; Hastie et al., 2009; Schapire, 2003) to relate the occurrence of Lampetra sp. ammocoetes with the environmental predictors. This method has a consistently high predictive performance, often superior to most traditional modeling techniques such as Generalized Linear Models (GLMs) or Generalized Additive Models (GAMs) (Elith et al., 2006, 2008; Leathwick et al., 2006, 2008; Parisien and Moritz, 2009). BRT combines the strengths of regression trees with boosting, an optimization technique that reduces predictive deviance in a stagewise fashion by combining numerous simple regression trees into a single, more robust model (Elith et al., 2008; Leathwick et al., 2006). Each successive tree focuses on modeling unexplained response deviance.

BRT models were fitted in R (R Development Core Team, 2006), using the "gbm" library (Ridgeway, 2006) with the code provided by Elith et al. (2008). All models included the species presence/ absence data as the response variable and the value for each of the environmental variables as the predictors. Optimal model parameters were determined by altering the tree complexity $(t c)$ and the learning rate $(l r)$ until predictive deviance was minimized without overfitting. The $t c$ represents the number of split points in each tree and, therefore, determine the maximum number of interactions adjusted. Ten-fold cross-validation was used to identify the optimal number of trees to use for each model and subsequently assess the predictive performance. In 10-fold cross validation the data set is partitioned into 10 folds or subsamples. Model calibration is performed using nine folds while the left-out fold is used for comparison with predicted values. The procedure is repeated 10 times until each fold is used for validation. This technique is commonly used in ecological studies (e.g. Capinha et al., 2011; Leathwick et al., 2008) mainly because it allows that all instances are used once for validation while simultaneously reduces the amount of data set-aside from model calibration. The area under the receiver operating characteristic curve (ROC) gives a measure of the degree to which fitted values discriminate between observed presences and absences (Crawley, 2007). Values of ROC range from 0.5 to 1 where a 1 indicates perfect discrimination of probabilities between presence and absence samples and a value of 0.5 indicates that model performance is no better than random. While models with ROC values above 0.6 are considered useful (Parisien and Moritz, 2009), values above 0.8 are considered very good, and above 0.9 are excellent (Lane et al., 2009).

In order to simplify the models we used a code developed by Elith et al. (2008) that eliminate non-informative variables by dropping the least important predictor, then resets the model sequentially and repeats the process until some stopping criterion is reached. Elith et al. (2006) emphasize the importance of simplification for small data sets, where redundant predictors may degrade the performance of the model by increasing the variance. This simplification process is run with a cross-validation procedure with 10 partitions that uses the average cross-validation error to decide how many variables can be removed from the original model without affecting the predictive performance (Elith et al., 2008).

The relative influence of each environmental variable in the model was determined using scripts from the "gbm" library. This relative influence is rescaled, so that the sum is 100 , with higher values indicating greater influence on the response (Froeschke et al., 2010). Partial dependent plots for most influential variables were created.

Predictions were projected across mainland Portugal using a procedure available in "gbm" that uses a form of logistic regression to generate probabilities of occurrence to any location ( $1 \mathrm{~km}^{2}$ grid) not sampled. The probability of a species occurring $(y=1)$, in a local with $X$ independent variables, $P(y=1 \mid X)$, is calculated using a logit: $\operatorname{logit}(P(y=1 \mid X=f(X))$ (Elith et al., 2008).

\subsection{Definition of conservation priorities}

The predictive distribution model, considering the probabilities of occurrence of Lampetra sp. in Portugal and the confirmed occurrences registered in the field, was used to define the base criteria that set four levels of river stretch conservation priority for these species, namely:

- Level 0 (no conservation interest): river stretches belonging to watersheds where the presence of Lampetra sp. was not confirmed and in watersheds with presence of Lampetra sp. but in river stretches presenting a probability of occurrence inferior to $30 \%$.

- Level 1 (moderate conservation priority): river stretches belonging to watersheds where the presence of Lampetra sp. was confirmed and where the probability of occurrence ranges between $30 \%$ and $40 \%$.

- Level 2 (high conservation priority): river stretches belonging to watersheds where the presence of Lampetra sp. was confirmed and where the probability of occurrence is above $40 \%$.

- Level 3 (maximum conservation priority): river stretches with confirmed presence of Lampetra sp., with the geographical limits of the designated section defined with a probability of occurrence criteria above $40 \%$.

The designation of conservation priorities for the migratory $L$. fluviatilis has to take into account the fact that this species needs uninterrupted river stretches to reach the spawning grounds, usually located in upstream reaches where temperature, oxygen conditions and substrate are suitable for spawning, egg incubation and early larval development. This considered, designated areas in watersheds where the presence of the anadromous species was confirmed should be adjusted to the criteria defined above. In this cases the designated stretch should be extended to the mouth of the basin, and with that it may not fulfill the probability of occurrence criteria ( $>40 \%$ ) defined to delimitate the up and downstream limits of the designated maximum conservation priority level water courses.

\section{Results}

\subsection{Prospection of Lampetra sp. ammocoetes}

In total 401 stations were sampled (Fig. 1). The number of sampled stations was lower than the initially proposed because: (i) in the southern basins, several preselected sampling stations were completely dry during the sampling period, due to the temporary regime of these typically Mediterranean river systems; and (ii) in the northern watersheds (especially in the upstream stretches of the Douro basin) the typical mountain characteristics of these water courses (i.e. strongly embedded valleys, sharp slopes, torrential regimes and coarse substrate) are not compatible with the presence of ammocoete beds due to the absence of sandy substrates, or at least pockets of sand, for burrowing behavior.

Lampreys were present only at $14.9 \%(N=60)$ of the total sampled sites. Of the 15 basins prospected, the presence of the genus Lampetra was registered only in eight, namely: Douro, small independent streams between Douro and Vouga river basins, Vouga, Mondego, Lis, small independent streams of Oeste, Tejo and Sado.

\subsection{Relationships between Lampetra sp. occurrence and environmental predictors}

The high correlation between some environmental variables resulted in the elimination of six variables: frain, wti, spi, meantemp, 


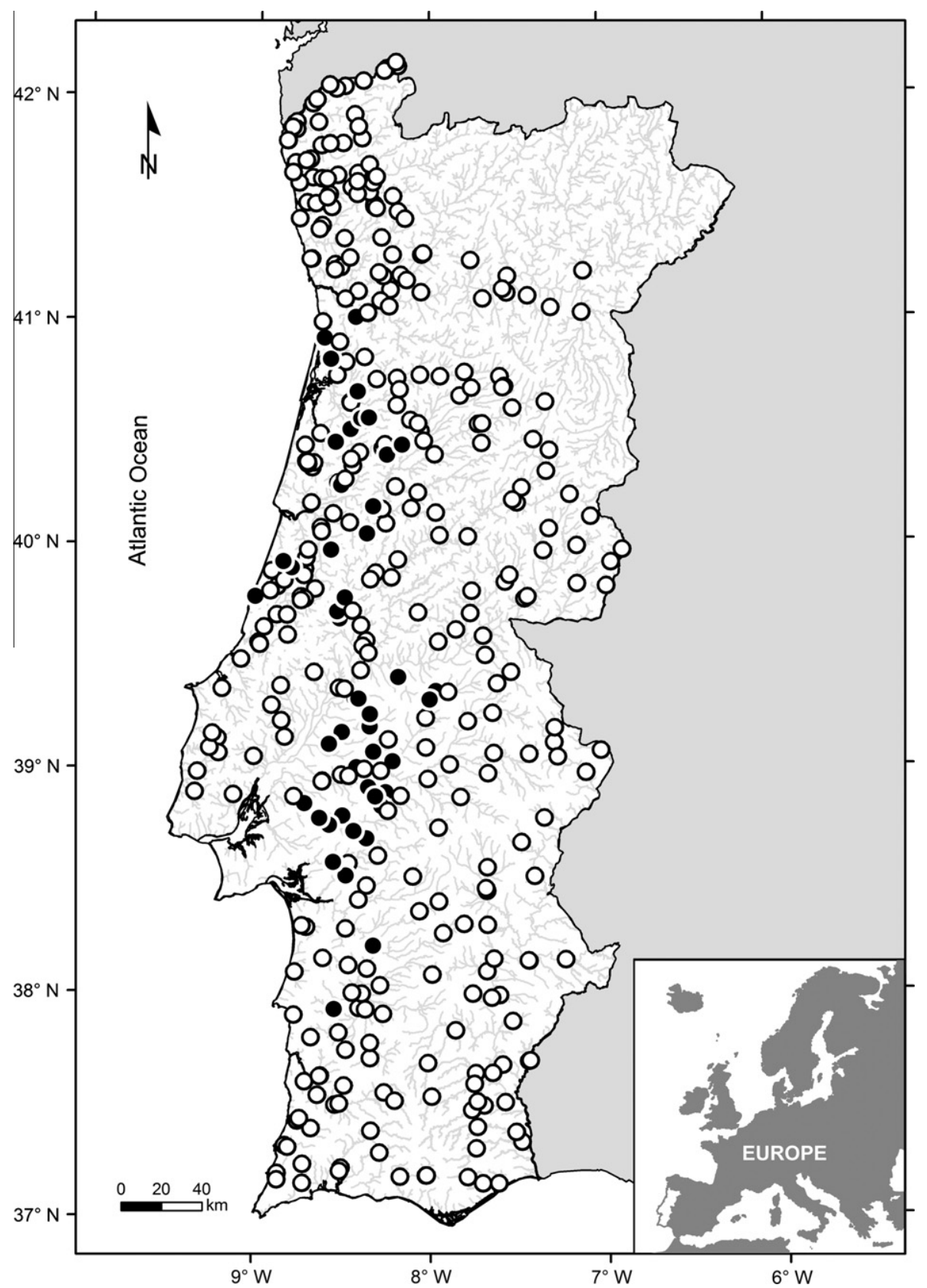

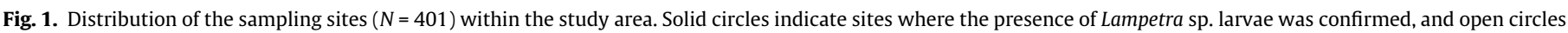
probable absence.

preca and use_nat. The predictors were reduced to the remaining 11 variables and this database was used to fit the model together with the presence-absence information.

The optimal model for Lampetra sp. uses a tree complexity of four, a learning rate of 0.001 , and a "bag fraction" of 0.5 . The simplification of the model resulted in the elimination of six predictors (slope, fcum, silt, use_art, use_agri, and populat) and improved the predictive performance of the model (Table 2). The evaluation of the simplified model suggests a very good predictive performance for independent data $(\mathrm{ROC}=0.877)$.

According to the recursive feature elimination procedure, the five strongest variables associated with Lampetra sp. distribution are essentially related with geomorphology of rivers (altitud, dist_co and sand) and climatic (precdrie and maxtemp). The average contributions of the most important predictors for BRT models relating the distribution of Lampetra sp. species to environment
Table 2

Predictive performance of BRT models using a tree complexity of four, a learning rate of 0.001 , and a "bag fraction" of 0.5 and relating occurrence of Lampetra sp. to environment, before and after simplification.

\begin{tabular}{lll}
\hline & 11 Predictors model & 5 Predictors model \\
\hline No. of sites & 401 & 401 \\
No. of predictors & 11 & 5 \\
No. of trees & 4250 & 5910 \\
ROC & 0.838 & 0.877 \\
\hline
\end{tabular}

were: altitude with $25.3 \%$ of contribution; distance to coast with 20.7\%; precipitation of driest month with $19.6 \%$; sand with $17.4 \%$ and maximum temperature of warmest month with $17.0 \%$ of contribution.

Fitted functions (Fig. 2) indicate that Lampetra sp. occurrence are associated with river segments combining altitudes lower than 
$170 \mathrm{~m}$, distances to coast up to $150 \mathrm{~km}$, and predominance of sand $(>70 \%)$ in the substrate. The climatic predictors indicates that this species is detected most frequently between 5 and $15 \mathrm{~mm}$ of precipitation of the driest month and between 26 and $30^{\circ} \mathrm{C}$ of maximum temperature of the warmest month.

\subsection{Spatial predictions of Lampetra sp. probability of occurrence}

The prediction of the probability of occurrence of Lampetra sp. for the entire continental Portuguese territory derived from the BRT model with a tree size of 4 is spatially distributed as displayed in Fig. 3. The probability of occurrence of Lampetra sp. ranged from $0.5 \%$ to $86.6 \%$. Confirmed occurrences were found in sites with an average ( \pm standard deviation) probability of occurrence of $0.39 \%$ $( \pm 0.21)$; whereas probable absence was detected in sites with a lower probability of occurrence $(0.06 \%, \pm 0.09)$. The highest probability of occurrence of Lampetra sp. occur between the basins of the Douro, in the north, and Sado, in the south, exception made to the most interior region of this central territory of the country (Fig. 3). Moderately high probability of occurrence (up to 40\%) was also predicted for south-western Portuguese coast and in the Setúbal region (between Tejo and Sado estuaries), areas where the Lampetra sp. presence was not detected.

\subsection{Map of conservation priorities}

The stretches of rivers delimited with different priorities of conservation for Lampetra sp. are presented in Fig. 4. In total, $1718 \mathrm{~km}$ of rivers were assigned with one of the three levels of conservation priority which represents $6.1 \%$ of the total length of the Portuguese hydrographic systems. The maximum level of conservation priority was the one with the longer length of designated water courses, $847 \mathrm{~km}$ (c.f. Table 3), followed by the high priority level with $484 \mathrm{~km}$ and the moderate level with $386 \mathrm{~km}$.

\section{Discussion}

\subsection{Influence of environmental variables on the distribution of Lampetra $s p$}

The large sampling survey conducted for this study result in the enlargement of the previously known distribution of Lampetra sp. in Portugal (Cabral et al., 2005; Espanhol et al., 2007; Mateus et al., 2011b). Lampreys occur from the Inha river (a tributary of the Douro river basin) in the north, to S. Domingos stream (Sado basin) in the south. The map of probability of occurrence was consistent with the data collected during the field work and the empirical perception of the researchers in identifying, a priori, a set of hydromorphological characteristics that potentiate lamprey presence. Central Portugal was the region with the higher probability of occurrence, except for the innermost region of the country and the right margin of the Tejo river basin (with the exception for the Nabão sub-river basin).

The distribution of the genus Lampetra in Portugal can be largely explained by five environmental variables: 'altitude', 'distance to coast', 'precipitation of driest month', 'percentage of sand' and 'maximum temperature of warmest month'. Geomorphological variables explained most of the distribution (63.4\%) but climatic variables are also identified as very important (36.6\%).

'Altitude' is the strongest predictor of these species distribution, with predicted occurrence peaking at low altitudes $(<170 \mathrm{~m})$, before tailing off in higher elevations. 'Altitude' is a variable with an indirect effect on species distribution (Austin, 2002). Their correlation with species distribution is due to their location-dependent correlation with variables such as gradient, which generally increases with elevation (Austin, 2002). Gradient is widely recognized as the main macroscale variable influencing the existence of suitable conditions for ammocoete colonization because of its influence in the current velocity and thus, the substrate granulometry and the accumulation of organic debris, an important food source for these microphagous feeders (Hardisty and Potter, 1971). The stream gradient index, which measures linear stream slope, was not included in our analyses because it is largely collinear with 'river slope', a predictor we tested. Guisan and Zimmermann (2000) point out that in many cases indirect variables, such as 'altitude', usually replace a combination of different resources and direct variables in a simple way and this is likely to lead to robust predictive models (Austin, 2002).

'Distance to coast' has the second highest environmental contribution to overall model outcomes. Lampreys occur up to $150 \mathrm{~km}$ from coast, which means that they do not occur in the headwaters of rivers. Trimodal variations in the response curve are related with the different size of the river basins in which lampreys occurs in Portugal, that vary from the very small independent river basins (e.g. the small independent streams between Douro and Vouga river basins, Lis and the small independent streams of Oeste that drain directly to the Atlantic Ocean), to the larger rivers systems where lampreys only occur in tributaries farther from the coast (Douro, Vouga, Mondego, Tejo and Sado rivers basins). 'Distance to coast' reflects the structure of the rivers from the headwaters to mouth (Vannote et al., 1980). In the downstream stretches of
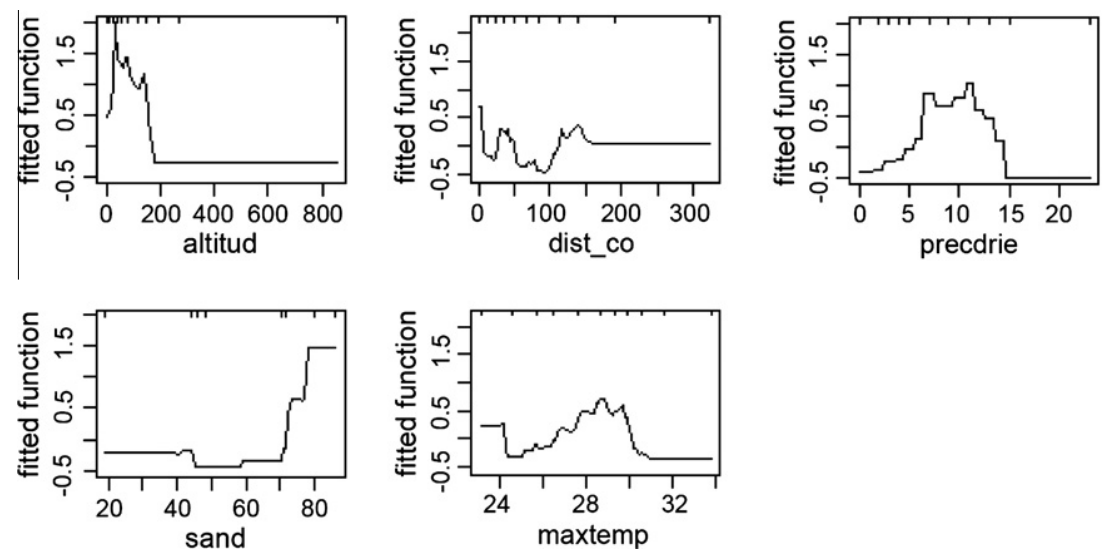

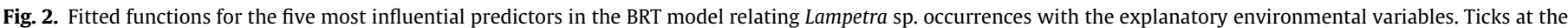

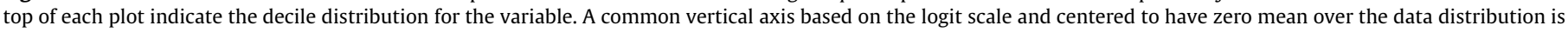
used for each plot. 


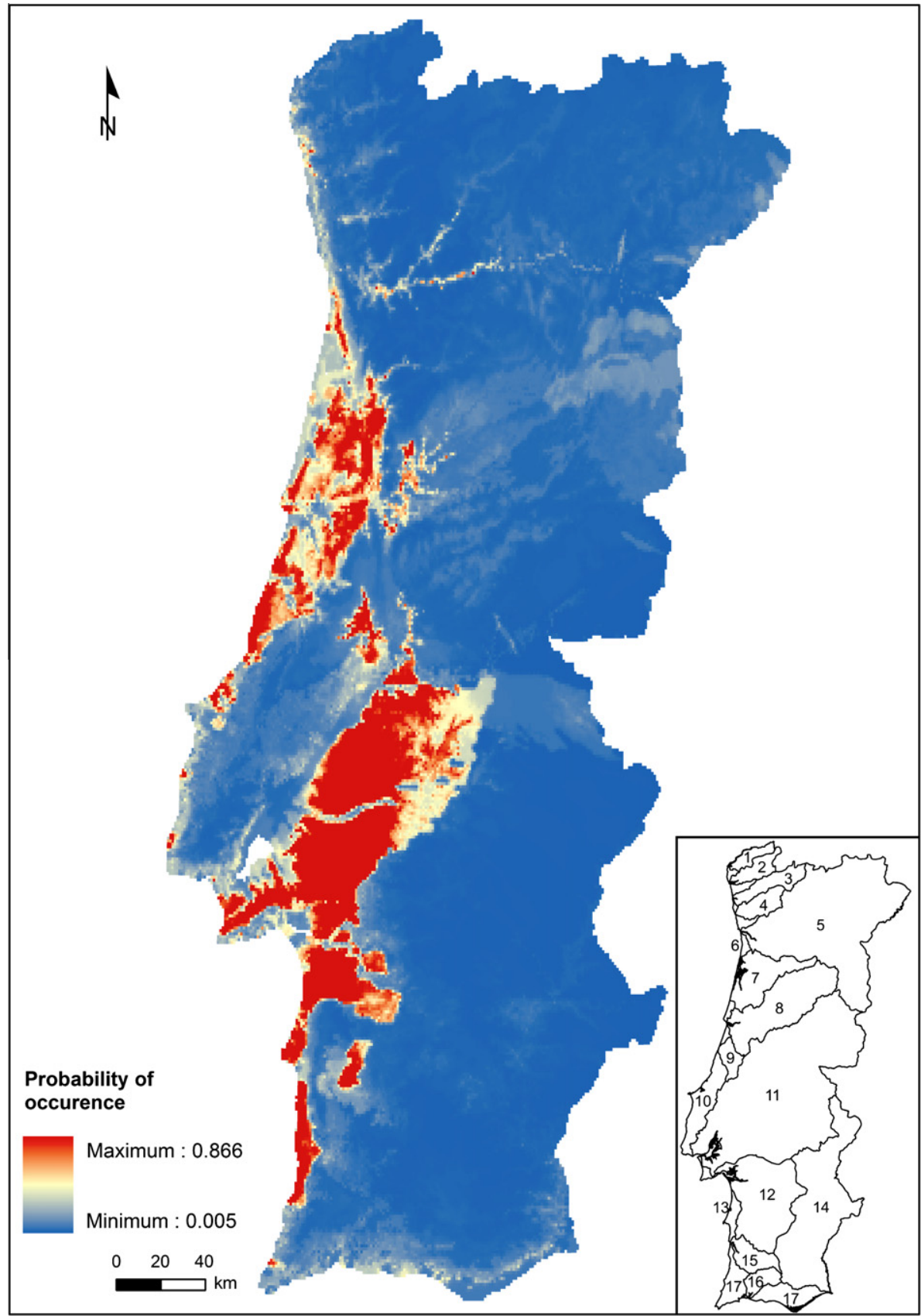

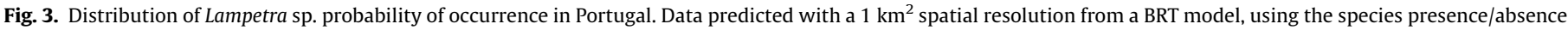

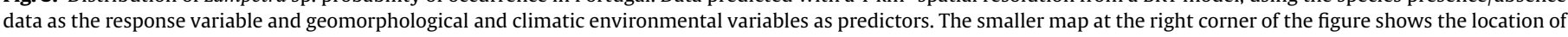

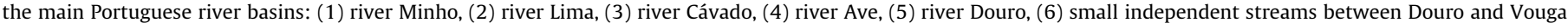

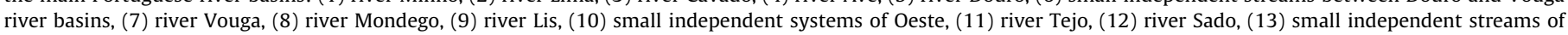
Alentejo, (14) river Guadiana, (15) river Mira, (16) river Arade, and (17) small independent streams of Algarve.

the rivers the current velocity is usually slow, allowing the deposition of soft silt and sand that constitute the preferred substrate composition for ammocoetes (Almeida and Quintella, 2002; Hardisty, 1979). Distance to coast is also related with the probability of presence of barriers which augments with the increasing distance from the river mouth and prevent the reproductive migration. The presence of barriers to migration was one of the parameters considered by Goodwin et al. (2008) as determinant in the distribution of the genus Lampetra. Although $L$. planeri adults do not migrate out of rivers to feed they perform small upstream movements to find suitable spawning areas (Hardisty and Potter, 1971), so this species also requires clear migration routes, albeit over consider- ably shorter distances than the anadromous L. fluviatilis (Goodwin et al., 2008).

Of the predictors within the geomorphological typology, percentage of sand had the smallest contribution to the distribution model. Unlike altitude and distance to coast, the percentage of sand affects directly the presence of lampreys, which reinforces the importance of this variable to these species. In this study, the presence of lampreys is very frequent when more than $70 \%$ of the substrate particles in the soil are composed by sand. This pattern is consistent with the results from several other studies with ammocoetes belonging to distinct species of lampreys (e.g. Almeida and Quintella, 2002; Hardisty and Potter, 1971; Young et al., 


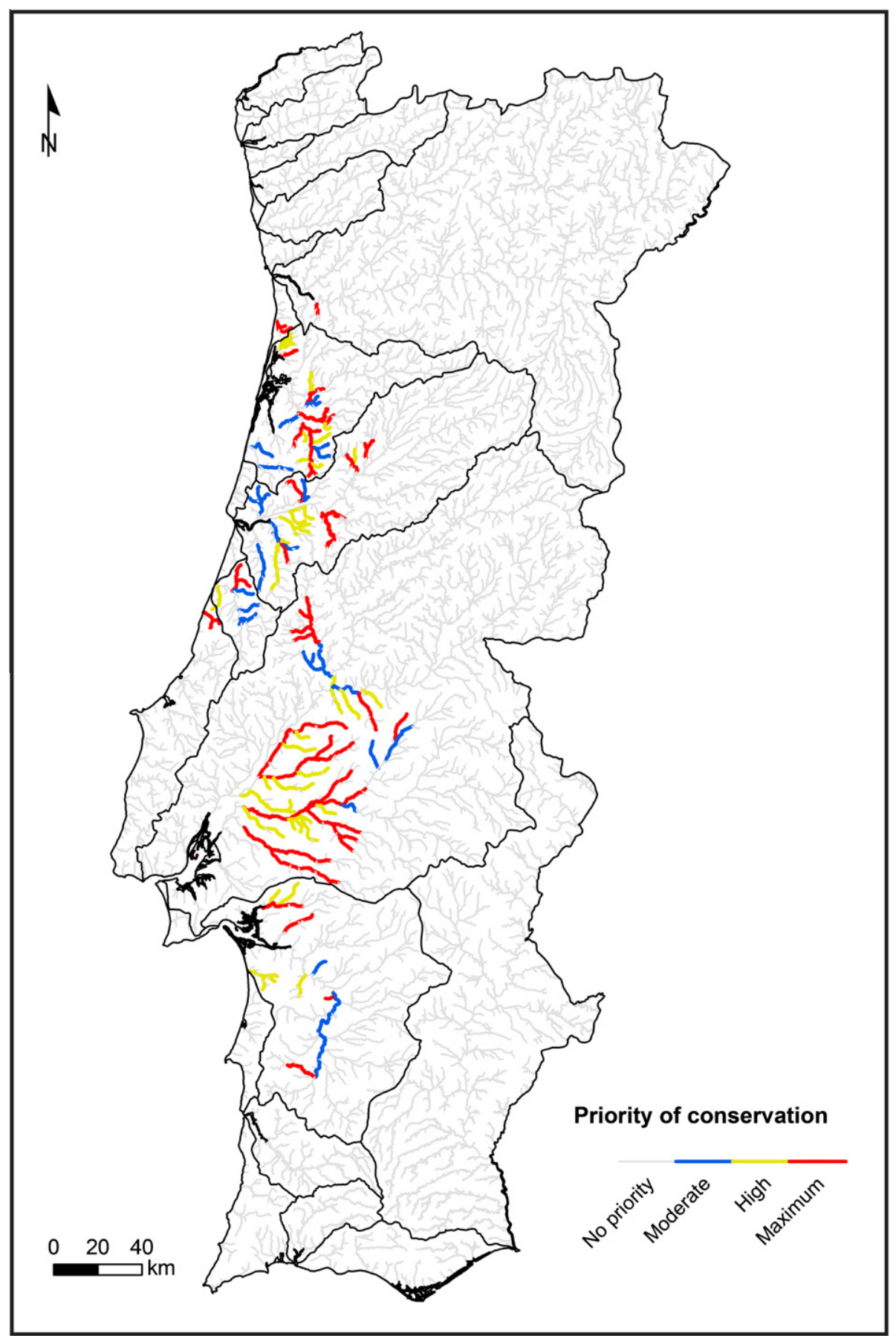

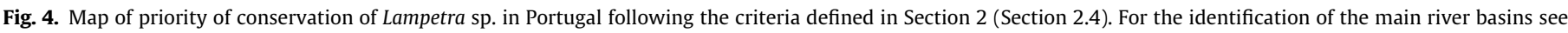
Fig. 3.

1990). An appropriate river substrate is an essential environmental characteristic for the development of larval lampreys, not only because it allows burrowing, but also because it helps to maintain a vital water flux. The detritivorous lamprey larvae depend on a unidirectional flow of water through their branchial chamber, for the provision of food and exchange of respiratory gases and metabolic wastes (Hardisty and Potter, 1971). In regions where the abundance of sand is low lampreys are absent. Even though the presence of Lampetra sp. might be expected in the north of Portugal due to the distribution range of the genus in Europe, the levels of sand in these regions are in order of $40 \%$, far from the $70 \%$ threshold identified by the distribution model as important for the pres- ence of lampreys. The low abundance of sand is also the explanation for the low probabilities of occurrence found in the right margin of the Tejo river, with exception for the Nabão subriver basin, where the restricted area with a high percentage of sand might explain the confirmed presence of lampreys in this Tejo tributary.

Climatic variables were considered important by the distribution model to explain the absence of the genus in the southern basins of the country. Portugal has a considerable spatial heterogeneity from the climatic, geomorphologic and hydrologic perspectives. The southern region of the country is characterized by wet winters, dry and hot summers (ICA, 2011) and a typical 
Table 3

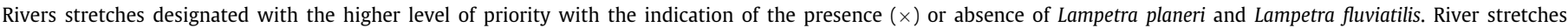
belonging to the evolutionary significant units (ESUs) identified in Mateus et al. (2011b) study are assigned with the respective ESU.

\begin{tabular}{|c|c|c|c|c|c|}
\hline Catchment & River & $\begin{array}{l}\text { River } \\
\text { stretch }(\mathrm{km})\end{array}$ & $\begin{array}{l}\text { L. fluviatilis } \\
\text { (river lamprey) }\end{array}$ & $\begin{array}{l}\text { L. planeri } \\
\text { (brook lamprey) }\end{array}$ & $\begin{array}{l}\text { Evolutionary } \\
\text { significant unit (ESU) }\end{array}$ \\
\hline Douro & Inha river & 8 & & $\times$ & ESU IV \\
\hline $\begin{array}{l}\text { Small independent streams between } \\
\text { Douro and Vouga river basins }\end{array}$ & Mangas stream & 18 & & $\times$ & ESU III \\
\hline Vouga & $\begin{array}{l}\text { Negro river } \\
\text { Vouga river } \\
\text { Águeda- Alfusqueiro rivers } \\
\text { Cértima river } \\
\text { Levira river }\end{array}$ & $\begin{array}{l}11 \\
17 \\
39 \\
41 \\
15\end{array}$ & & $\begin{array}{l}\times \\
\times \\
\times \\
\times \\
\times\end{array}$ & $\begin{array}{l}\text { ESU III }^{\mathrm{a}} \\
\text { ESU III }^{\mathrm{a}} \\
\text { ESU III } \\
\text { ESU III }^{\mathrm{a}} \\
\text { ESU III }^{\mathrm{a}}\end{array}$ \\
\hline Mondego & $\begin{array}{l}\text { Mortágua stream } \\
\text { Criz river } \\
\text { Ançã stream } \\
\text { Ceira river } \\
\text { Corvo stream } \\
\text { Anços river }\end{array}$ & $\begin{array}{l}14 \\
14 \\
17 \\
20 \\
31 \\
13\end{array}$ & & $\begin{array}{l}\times \\
\times \\
\times \\
\times \\
\times \\
\times\end{array}$ & $\begin{array}{l}\text { ESU IV }^{\mathrm{a}} \\
\text { ESU IV } \\
\text { ESU IV }^{\mathrm{a}} \\
\text { ESU IV }^{\mathrm{a}} \\
\text { ESU IV } \\
\text { ESU IV }\end{array}$ \\
\hline Lis & Leca stream & 24 & & $\times$ & ESU IV \\
\hline Small independent streams of Oeste & S. Pedro stream & 16 & & $\times$ & ESU IV \\
\hline Tejo & $\begin{array}{l}\text { Nabão river } \\
\text { Torto river } \\
\text { Ulme stream } \\
\text { Muge stream } \\
\text { Longomel stream } \\
\text { Erra stream } \\
\text { Sorraia river } \\
\text { Divôr river } \\
\text { Almansor river }\end{array}$ & $\begin{array}{l}60 \\
21 \\
62 \\
72 \\
16 \\
32 \\
72 \\
57 \\
92\end{array}$ & $\begin{array}{l} \\
\\
\\
\\
\\
\times \\
\times \\
\times \\
\times \\
\times\end{array}$ & $\begin{array}{l}\times \\
\times \\
\times \\
\times \\
\times \\
\times \\
\times \\
\times \\
\times\end{array}$ & $\begin{array}{l}\text { ESU II } \\
\text { ESU IV } \\
\text { ESU IV } \\
\text { ESU IV } \\
\text { ESU IV } \\
\text { ESU IV } \\
\text { ESU IV } \\
\text { ESU IV }^{\mathrm{a}} \\
\text { ESU IV }^{\mathrm{a}}\end{array}$ \\
\hline Sado & $\begin{array}{l}\text { Marateca stream } \\
\text { S. Martinho stream } \\
\text { Barranco Brejo Largo stream } \\
\text { S. Domingos stream }\end{array}$ & $\begin{array}{r}23 \\
18 \\
5 \\
19\end{array}$ & & $\begin{array}{l}\times \\
\times \\
\times \\
\times\end{array}$ & $\begin{array}{l}\text { ESU I } \\
\text { ESU I }^{\mathrm{a}} \\
\text { ESU I I }^{\mathrm{a}} \\
\text { ESU I }^{\mathrm{a}}\end{array}$ \\
\hline
\end{tabular}

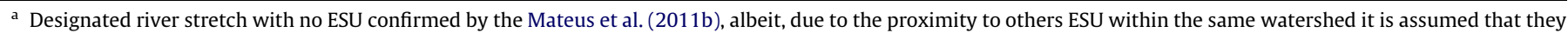
belong to the same evolutionary significant unit.

intermittence in river flow. Discharge data are difficult to obtain for many of the river basins (Ducharne et al., 2003) so we used precipitation as an indicator of the amount of water received in a basin (e.g. Lassalle et al., 2008). Also, variables such as rainfall are likely to be the limiting factor in any water balance model when a species is at the limits of its distribution (Austin, 2002). In fact, precipitation was the third most important variable to the prediction of Lampetra sp. distribution in Portugal, with the highest probability of occurrence ranging between 5 and $15 \mathrm{~mm}$. This result indicates that water availability influences the distribution of the genus Lampetra and, in places where it is low (systems with Mediterranean influences, in south of the country) or very high (headwater rivers, found in central and northern Portugal), the probability of occurrence of the genus is lower.

Temperature is the environmental variable that at a global scale best explains lampreys' distribution in the world. Lampreys have an antitropical distribution, generally found north and south of the $20^{\circ}$ isotherm, with average lethal temperatures around $28^{\circ} \mathrm{C}$ (Potter, 1980). This value was very near to the thermic limit identified in our study: lampreys were found in areas where the average maximum temperature of the warmest month did not exceed $30{ }^{\circ} \mathrm{C}$. Temperature is not usually identified as an important predictor of species distribution at small geographic levels, but since Portugal represents the southern limit of distribution of Lampetra sp. in Europe, this variable assumes particular importance in a relatively small study area. The high temperatures and the intermittent flow regime of southern rivers may explain the absence of Lampetra sp. in the small independent streams of Algarve region and in the Guadiana river basin. However, in the south-western coast, i.e. small independent streams of Alentejo and northwestern part of small independent streams of Algarve region, the probabilities are moderate, which means that the conditions for the presence of lampreys are, theoretically, present in these streams. The registered absence of lampreys in this littoral area can, eventually, be explained by the reduced dimensions of this independent river basins and the absence of fluvial connectivity between them. Keeping in mind that this littoral area is in the south of the country, a region with a strong Mediterranean influence, it is probable that a past existence of a drier period could have been responsible for the disappearance of the non-migratory resident lamprey populations that might have colonized these water courses in the past.

Another region that presents moderate probabilities of occurrence with no registered presence of lampreys is the Setúbal area. This is a very disturbed region, being affected by a considerable number of anthropogenic pressures, such as high population density and several industry types. Although the environmental conditions theoretically necessary for the presence of lampreys are present, the river degradation, namely aquatic pollution, to which these streams are subjected, are probably not compatible with the presence of lampreys. In the initial model, some variables related to the environmental stressors were included because they can certainly affect the distribution of lampreys and other aquatic organisms, but were not selected as relevant predictors in the final model. The apparent absence of lampreys in areas with favorable conditions for its presence but with a high degree of environmental degradation is probably indicative that the degradation of river systems is not compatible with the occurrence of these species.

In this study, both historical and contemporary factors were identified to constrain Lampetra sp. distribution at a regional level. The importance of historical factors in the distribution of freshwa- 
ter fishes (Filipe et al., 2009) is here supported since, 'altitude', 'distance to coast' and 'sand' explained more than half of the variation (63.4\%) in the distribution of this genus. Although, to fully explain the distribution of lampreys in Portugal, it is necessary to take into consideration contemporary environmental variables since precipitation and temperature were identified to explain $36.6 \%$ of the model distribution. Lassalle et al. (2008) predicts that climate change by the end of the 21 st century is estimated to severely affect the distribution of the sea lamprey in Europe, particularly in the Iberian Peninsula. The sea lamprey and the European brook and river lampreys have roughly the same latitudinal distribution in Europe (Mateus et al., 2012). Thus, it seems probable that a global warming scenario can severely affect also the southern Lampetra sp. populations due to the increase of temperature above the lethal thermal limit for lampreys and consequent decrease in water availability. According to the Lassalle et al. (2008) predictions, lampreys might disappear from the southern river basins of the Iberian Peninsula, remaining only in the northern ones, like River Minho in Portugal and the watersheds of the Spanish Galicia region. For the Lampetra genus this prediction probably means the almost absolute disappearance of $L$. fluviatilis and $L$. planeri from the Iberian Peninsula since most of their population nucleus are found in southwestern region (Mateus et al., 2012).

\subsection{Model performance}

The selected suite of environmental variables allowed the development of a robust model with a ROC of 0.877 . This apparently high predictive performance must take into account the very low prevalence of these species in the data set (Bio, 2000; Elith et al., 2006). That is, the apparently high performance of these models will be influenced in some measure by their success at predicting the absences which predominate in the data for these species (Leathwick et al., 2008). Lampreys have a relatively low prevalence $(14.9 \%)$ in the current dataset. However, the high overall model accuracy suggests this was not a problem and the ability to discriminate between presence and absence can be attributed to accurately modeling the restricted subset of environmental conditions in which species occurs. Furthermore, the high explanation of response variance provides confidence in using the model to assess how landscape and climate features regulate the distribution of Lampetra sp. within Portuguese river systems.

\subsection{Prioritizing conservation of Lampetra $s p$}

Areas of higher probability of occurrence and most of the confirmed presences are generally outside the Portuguese National Protected Areas Network, so, most of the areas identified as potentially important for the occurrence of Lampetra sp. lack any kind of legal protection (ICNB, 2005). Consequently, conservation actions aiming to maintain or restore favorable conditions for the species are even more difficult to implement. Several anthropogenic activities that are responsible for the species decline (e.g. water pollution, water abstraction, loss of connectivity due the construction of dams and weirs and dredging activities to extract sand from the river bed) were identified in most of the maximum priority areas (Ferreira, 2011). In order to prevent the regression of the distribution area of Lampetra sp. a national conservation strategy for these species is urgently needed which may consider, as one of the first measures, the constitution of Special Areas of Conservation, including the areas identified with high probability of occurrence in the present study. The presence of the rare $L$. fluviatilis in a river stretch should be taken in account when prioritizing areas to preserve. This species only occurs in $30 \%(253 \mathrm{~km})$ of the maximum priority conservation areas, and this river extension is clear overestimated in terms of available habitat by the inclusion of the river stretches that this species only use during the migratory periods.

Predictive and responsive statistical models are commonly used for conservation planning because the alternatives (e.g. survey data) are incomplete or spatially biased (Wilson et al., 2004). In the Lampetra sp. probability of occurrence model developed for Portugal, we can see the existence of lower probability areas of occurrence connecting higher ones. This suggests a tendency to a fragmented lamprey distribution which, in combination with low population density and habitat specialization, exacerbates the high vulnerability of these species to stochastic extinction (e.g., Soule, 1987). This is particularly important, for the southern populations (Tejo and Sado basins) where the presence of temporary watersheds, with severe periods of drought that seasonally decrease the rivers ability to dilute pollutants, diminishes the conditions for survival of aquatic organisms, including lampreys. Additionally, the overexploitation of water resources for agricultural uses, common in the southern Portuguese river basins, is responsible for a significant decrease in the available habitat for the different life stages and ecological processes of species with such a complex life cycle.

The Iberian Peninsula seems to have played a major role as a glacial refugium for lampreys of the genus Lampetra (Espanhol et al., 2007). The high genetic diversity observed in Iberian Peninsula Lampetra populations, where four highly divergent allopatric evolutionary lineages were identified, is probably the result of refugial persistence and subsequent accumulation of variation over several ice ages, whereas the low levels of genetic diversity observed in central and northern Europe should reflect a rapid postglacial colonization (Mateus et al., 2011b). The high level of genetic divergence between the four lineages identified in the Iberian Peninsula suggests that sufficient time has apparently passed by to originate a complex of incipient or cryptic resident species which allowed the definition of four evolutionary significant units (ESUs) for L. planeri and one ESU for L. fluviatilis (Mateus et al., 2011b). River stretches with the higher priority of conservation are identified in Table 3. L. fluviatilis and $L$. planeri coexist in only $30 \%$ of the rivers assigned with the maximum level of conservation priority. The rivers assigned with the highest priority of conservation were associated with the respective evolutionary significant unit (ESU), as identified in Mateus et al. (2011b) study. Following this procedure, the river stretches assigned with the maximum conservation priority belonging to the Sado river basin were associated to the ESU-I; the ones belonging to the Nabão sub-river basin were associated to the ESU-II; the ESU-III groups the river stretches assigned with the maximum conservation priority from the Vouga river basin plus the Mangas stream (system belonging to the small independent streams between Douro and Vouga river basins); the ESU-IV embraces the Inha river, in Douro river basin, the rivers assigned with the maximum conservation priority from the Mondego and Lis river basins, the S. Pedro stream (system belonging to the small independent streams of Oeste) and the rivers assigned with the maximum conservation priority from the Tejo river basin, with exception for the Nabão sub-river basin. Although European river and brook lampreys are globally considered 'Least Concern', because they remain a widely distributed taxa throughout Europe (IUCN, 2010), the higher genetic diversity within the Iberian Peninsula, and the evidence that points to the origin of northern European Lampetra populations from multiple dispersal events from the Iberian populations after a glacial event, is indicative of the importance of conserving Portuguese Lampetra populations. The establishment of SACs in river stretches considered important for these species, identified in this study with the higher level of conservation priority, is a powerful management tool that might guarantee the preservation of the identified ESUs, in a region were the bulk of the genetic background diversity of these species is still present. 
What we propose in the present paper is to designate SAC's all the river stretches classified with the maximum priority level of conservation. This is justifiable because we are dealing with species considered 'Critically Endangered' in a region where most of the genetic diversity of the species was detected (Espanhol et al., 2007; Mateus et al., 2011b, 2012). If, by a number of reasons, a restriction in the number of designated areas is imposed by the administration, river stretches where both Lampetra species occur should be considered priority when compared with systems where only one of the lamprey species is present (see Table 3). The four highly divergent allopatric evolutionary lineages for Lampetra populations in the Iberian Peninsula, which allowed the definition of four ESUs in the study of Mateus et al. (2011b), should also be taken in account when prioritizing rivers for conservation. At least, each ESU should be represented in the designated SAC stretches.

\section{Acknowledgements}

We would like to thank to Carlos Antunes, Duarte Mendes, Filipe Romão, Hugo Monteiro, Marta Lourenço, Nuno Andrade, Paula Valadas, Ricardo Castilho and Tadeu Pereira for helping with the field sampling. Thanks are also do to the Fluviário de Mora for their logistical support. This research was financially supported by EDP (Energias de Portugal) with the award Fundo EDP para a Biodiversidade 2008 and by Fundação para a Ciência e a Tecnologia (FCT) through its pluriannual funding program to the Centre of Oceanography (PEst-OE/MAR/ UI0199/2011). Licensing to collect the samples was provided by two government institutions, the Autoridade Florestal Nacional (AFN) and Instituto de Conservação da Natureza e Biodiversidade (ICNB).

\section{References}

Almaça, C., Collares-Pereira, M.J., 1988. On the occurrence of the European river lamprey, Lampetra fluviatilis L., in the Iberian Peninsula. Cybium 12, 9-15.

Almeida, P.R., Quintella, B.R., 2002. Larval habitat of the sea lamprey (Petromyzon marinus) in the River Mondego (Portugal). In: Collares Pereira, M.J., Coelho, M.M. Cowx, I.G. (Eds.), Freshwater Fish Conservation: Options for the Future. Fishing News Books. Blackwell Science, Oxford, pp. 121-130.

Almeida, P.R., Quintella, B.R., Dias, N.M., Andrade, N., 2002. The anadromous sea lamprey in Portugal: biology and conservation perspectives. In: Proceedings of the International Congress on the Biology of Fishes - The Biology of Lampreys. Vancouver, Canada, pp. 49-58.

Almeida, P.R., Maia, C., Quintella, B.R., Antunes, C., Gomes, N., Alexandre, C.M. Mateus, C., Mendes, D., Ferreira, A.F., Lopes, J., 2011. National conservation plan of the European river and brook lampreys. Final Report. EDP - Energias de Portugal, S.A., Portugal.

Austin, M.P., 2002. Spatial prediction of species distribution: an interface between ecological theory and statistical modeling. Ecol. Model. 157, 101-118.

Baldaque da Silva, A.A., 1891. Estado Actual das Pescas de Portugal. Imprensa Nacional, Lisbon.

Beamish, F.W.H., Jebbink, J., 1994. Abundance of lamprey larvae and physical habitat. Environ. Biol. Fish. 39, 209-214.

Bio, A.M.F., 2000. Does Vegetation Suit Our Models? Data and Model Assumptions and the Assessment of Species Distribution in Space. Ph.D. Thesis, Utrecht University, Utrecht

Blank, M., Jürss, K., Bastrop, R., 2008. A mitochondrial multigene approach contributing to the systematics of the brook and river lampreys and the phylogenetic position of Eudontomyzon mariae. Can. J. Fish. Aquat. Sci. 65, 2780 2790.

Böhner, J., Köthe, R., Conrad, O., Gross, J., Ringeler, A., Selige, T., 2002. Soil regionalisation by means of terrain analysis and process parameterization. In: Micheli, E., Nachtergaele, F., Montanarella, L. (Eds.), Soil Classification 2001. EUR 20398 EN. The European Soil Bureau. Joint Research Centre, Ispra, pp. 213-222.

Cabral, M.J., Almeida, J., Almeida, P.R., Dellinger, T., Ferrand, N., Oliveira, M.E Palmeirim, J.M., Queiroz, A.I., Rogado, L., Santos-Reis, M. (Eds.), 2005. Livro Vermelho dos Vertebrados de Portugal. Instituto de Conservação da Natureza, Lisbon.

Capinha, C., Leung, B., Anastácio, P., 2011. Predicting worldwide invasiveness for four major problematic decapods: an evaluation of using different calibration sets. Ecography 34, 448-459.

Crawley, M.J., 2007. The R Book. John Wiley \& Sons, Ltd., West Sussex, England.

Doadrio, I., 2001. Atlas y Libro Rojo de los Peces Continentales de España. Dirección General de Conservación de la Naturaleza, Museo Nacional de Ciencias Naturales, Madrid.
Docker, M.F., 2009. A Review of the evolution of nonparasitism in lampreys and an update of the paired species concept. In: Brown, L.R., Chase, S.D., Mesa, M.G. Beamish, R.J., Moyle, P.B. (Eds.), Biology, Management, and Conservation of Lampreys in North America. American Fisheries Society, Symposium 72, Bethesda, pp. 71-114

Ducharne, A., Golaz, C., Leblois, E., Laval, K., Polcher, J., Ledoux, E., de Marsily, G., 2003. Development of a high resolution runoff routing model, calibration and application to assess runoff from the LMD GCM. J. Hydrol. 280, 207-228.

EEA, 2010. European Environmental Agency. Corine Land Cover 2000. Version 13. <http://www.eea.europa.eu/themes/landuse/interactive/clc-download> (accessed 07.04.10).

Elith, J., Leathwick, J.R., Hastie, T., 2008. A working guide to boosted regression trees. J. Anim. Ecol. 77, 802-813.

Elith, J., Graham, C.H., Anderson, R.P., Dudík, M., Ferrier, S., Guisan, A., Hijmans, R.J., Huettmann, F., Leathwick, J.R., Lehmann, A., Li, J., Lohmann, L.G., Loiselle, B.A., Manion, G., Moritz, C., Nakamura, M., Nakazawa, Y., Overton, J.Mc.C., Peterson, A.T., Phillips, S.J., Richardson, K.S., Scachetti-Pereira, R., Schapire, R.E., Soberón, J., Williams, S., Wisz, M.S., Zimmermann, N.E., 2006. Novel methods improve prediction of species' distributions from occurrence data. Ecography 29, 129-151.

Eneqvist, P., 1937. The brook lamprey as an ecological modification of the river lamprey. On the river and brook lampreys of Sweden. Arkiv. Zool. 29, 1-22.

Erickson, T.R., Stefan, H.G., 2000. Linear air/water temperature correlations for streams during open water periods. J. Hydrol. Eng. 5, 317-321.

Espanhol, R., Almeida, P.R., Alves, M.J., 2007. Evolutionary history of lamprey paired species Lampetra fluviatilis (L.) and Lampetra planeri (Bloch) as inferred from mitochondrial DNA variation. Mol. Ecol. 16, 1909-1924.

ESRI, 2009. ArcGIS/ArcInfo for Windows XP. Version 9.3.1. Environmental System Research Institute, Redlands.

FAO/IIASA/ISRIC/ISSCAS/JRC, 2009. Harmonized World Soil Database. Version 1.1. FAO, Rome, Italy and IIASA, Laxenburg, Austria.

Ferreira, A.F., 2011. Distribuição e Preferências de Habitat da Lampreia-de-rio e da Lampreia-de-riacho em Portugal: Implicações Para a sua Gestão e Conservação. Universidade de Évora, Évora, Master thesis.

Filipe, A.F., Araújo, M.B., Doadrio, I., Angermeier, P.L., Collares-Pereira, M.J., 2009. Biogeography of Iberian freshwater fishes revisited: the roles of historical versus contemporary constraints. J. Biogeogr. 36, 2096-2110.

Friedman, J.H., 2001. Greedy function approximation: a gradient boosting machine. Ann. Stat. 29, 1189-1232.

Friedman, J.H., 2002. Stochastic gradient boosting. Comput. Stat. Data Anal. 38, 367378.

Froeschke, J., Stunz, G.W., Wildhaber, M.L., 2010. Environmental influences on the occurrence of coastal sharks in estuarine waters. Mar. Ecol.-Prog. Ser. 407, 279-292.

Gasith, A., Resh, V.H., 1999. Streams in Mediterranean climate regions: abiotic influences and biotic responses to predictable seasonal events. Ann. Rev. Ecol. Syst. $30,51-81$

Goodwin, C.E., Dick, J.T.A., Rogowski, D.L., Elwood, R.W., 2008. Lamprey (Lampetra fluviatilis and Lampetra planeri) ammocoete habitat associations at regional, catchment and microhabitat scales in Northern Ireland. Ecol. Freshw. Fish. 17, 542-553.

Guisan, A., Zimmermann, N.E., 2000. Predictive habitat distribution models in ecology. Ecol. Model. 135, 147-186.

Hardisty, M.W., 1986a. Petromyzon marinus Linnaeus, 1758. In: Holčík, J. (Ed.), The Freshwater Fishes of Europe, vol. 1, Part I - Petromyzontiformes. Aula-Verlag, Wiesbaden, pp. 94-116.

Hardisty, M.W., 1986b. Lampetra fluviatilis Linnaeus, 1758. In: Holčík, J. (Ed.), The freshwater fishes of Europe, vol. 1, Part I - Petromyzontiformes. Aula-Verlag, Wiesbaden, pp. 249-278.

Hardisty, M.W., 1986c. Lampetra planeri Bloch, 1758. In: Holčík, J. (Ed.), The freshwater fishes of Europe, vol. 1, Part I - Petromyzontiformes. Aula-Verlag, Wiesbaden, pp. 279-304.

Hardisty, M.W., 1979. Biology of the Cyclostomes. Chapman and Hall, London and New York.

Hardisty, M.W., Potter, I.C., 1971. The behavior, ecology and growth of larval lampreys. In: Hardisty, M.W., Potter, I.C. (Eds.), The Biology of Lampreys, vol. 1. Academic Press, London, pp. 127-247.

Hastie, T., Tibshirani, R., Friedman, J.H., 2009. The Elements of Statistical Learning: Data Mining, Inference, and Prediction, second ed. Springer-Verlag, New York.

Hijmans, R.J., Cameron, S.E., Parra, J.L., Jones, P.G., Jarvis, A., 2005. Very high resolution interpolated climate surfaces for global land areas. Int. J. Climatol. 25, 1965-1978.

Hubbs, C.L., Potter, I.C., 1971. Distribution, phylogeny and taxonomy. In: Hardisty, M.W., Potter, I.C. (Eds.), The Biology of Lampreys, vol. 1. Academic Press, London, pp. 1-77.

ICA, 2011. Iberian Climate Atlas: Air Temperature and Precipitation (1971-2000). Department of the State Meteorological Agency of Spain, Spain, and Department of Meteorology and Climatology of the Institute of Meteorology, Portugal. <http://www.meteo.pt/resources.www/docs_pontuais/ocorrencias/2011/ atlas_clima_iberico.pdf $>$ (accessed 06.02.12).

ICNB, 2005. Portal do Instituto para a Conservação da Natureza e Biodiversidade. Plano Sectorial da Rede Natura 2000. <http://www.icn.pt/psrn2000/> (accessed 27.03.11).

IUCN, 2010. IUCN Red List of Threatened Species. Version 2010.2. <www.iucnredlist.org> (accessed 09.08.10)

Jowett, I.G., 1990. Factors related to the distribution and abundance of brown and rainbow trout in New Zealand clear-water rivers. New Zeal. J. Mar. Fresh. 24 429-440. 
Kainua, K., Valtonen, T., 1980. Distribution and abundance of European river lamprey (Lampetra fluviatilis) larvae in the tree rivers running into Bothnian Bay. Can. J. Fish. Aquat. Sci. 37, 1960-1966.

Kroll, S.A., Llacer, C.N., Cano, M.C., Heras, J., 2009. The influence of land use on water quality and macroinvertebrate biotic indices in rivers within Castilla-La Mancha (Spain). Limnetica 28 (2), 203-214.

LandScan, 2010. Geographic Information Science and Technology. OakRidge National Laboratory. UT-Battelle. US Department of Energy. <http:// www.ornl.gov/sci/landscan/> (accessed 24.03.10).

Lane, J.Q., Raimondi, P.T., Kudela, R.M., 2009. Development of a logistic regression model for the prediction of toxigenic Pseudo-nitzschia blooms in Monterey Bay. California. Mar. Ecol.-Prog. Ser. 383, 37-51.

Lassalle, G., Béguer, M., Beaulaton, L., Rochard, E., 2008. Diadromous fish conservation plans need to consider global warming issues: an approach using biogeographical models. Biol. Conserv. 141, 1105-1118.

Leathwick, J.R., Elith, J., Francis, M.P., Hastie, T., Taylor, P., 2006. Variation in demersal fish species richness in the oceans surrounding New Zealand: an analysis using boosted regression trees. Mar. Ecol.-Prog. Ser. 321, 267-281.

Leathwick, J.R., Elith, J., Chadderton, W.L., Rowe, D., Hastie, T., 2008. Dispersal, disturbance, and the contrasting biogeographies of New Zealand's diadromous and non-diadromous fish species. J. Biogeogr. 35, 1481-1497.

Maitland, P.S., 2003. Ecology of the River, Brook and Sea Lamprey. Conserving Natura 2000, Rivers Ecology Series No. 5. Peterborough, English Nature. 52pp.

Malmqvist, B., 1980. Habitat selection of larval brook lampreys (Lampetra planeri, Bloch) in a south Swedish stream. Oecologia 45, 35-38.

Mateus, C.S., Quintella, B.R., Rodríguez-Muñoz, R., Almeida, P.R., 2011a. Presence of the genus Lampetra in Asturias (Northern Spain). Cybium 35, 162-164.

Mateus, C.S., Almeida, P.R., Quintella, B.R., Alves, M.J., 2011b. MtDNA markers reveal the existence of allopatric evolutionary lineages in the threatened lampreys Lampetra fluviatilis (L.) and Lampetra planeri (Bloch) in the Iberian glacial refugium. Conserv. Genet. 12, 1061-1074.

Mateus, C.S., Rodríguez-Muñoz, R., Quintella, B.R., Alves, M.J., Almeida, P.R., 2012. Lampreys of the Iberian Peninsula: distribution, population status and conservation. Endang. Species Res. 16, 183-198.

Moore, I.D., Burch, G.J., Mackenzie, D.H., 1988. Topographic effects on the distribution of surface soil water and the location of ephemeral gullies. Trans. Am. Soc. Agric. Engrs. 31, 1098-1107.

Morman, R.H., Cuddy, D.W., Rugen, P.C., 1980. Factors influencing the distribution of the sea lamprey (Petromyzon marinus) in the great lakes. Can. J. Fish. Aquat. Sci. 37, 1811-1826.

Parisien, M.A., Moritz, A.M., 2009. Environmental controls on the distribution of wildfire at multiple spatial scales. Ecol. Monogr. 79, 127-154.

Perea, S., Garzón, P., González, J.L., Almada, V.C., Pereira, A., Doadrio, I., 2011. New distribution data on Spanish autochthonous species of freshwater fish. Graellsia 67, 91-102.
Poff, N.L., 1997. Landscape filters and species traits: towards mechanistic understanding and prediction in stream ecology. J. N. Am. Benthol. Soc. 16, 391-409.

Poff, N.L., Allan, D.J., 1995. Functional organization of stream fish assemblages in relation to hydrological variability. Ecology 76, 606-627.

Poff, N.L., Allen, J.D., Bain, M.B., Karr, J.R., Prestegaard, K.L., Richter, B.D., Sparks, R.E Stromberg, J.C., 1997. The natural flow regime: a paradigm for river conservation and restoration. BioScience 47, 769-784.

Potter, I.C., 1980. The petromyzontiformes with particular reference to paired species. Can. J. Fish. Aquat. Sci. 37, 1596-1615.

Potter, I.C., Osborne, T.S., 1975. The systematics of British larval lampreys. J. Zool. 76 , 311-329.

Primack, P.B., 1995. A Primer of Conservation Biology, third ed. Sinauer Associates, Inc., Sunderland, Massachusetts, USA.

R Development Core Team, 2006. R: A Language and Environment for Statistica Computing. Version 2.7.1. R Foundation for Statistical Computing, Vienna.

Richardson, J., Boubée, J.A.T., West, D.W., 1994. Thermal tolerance and preference of some native New Zealand freshwater fish. New Zeal. J. Mar. Fresh. 28, 399-407.

Richter, B.D., Mathews, R., Harrison, D.L., Wigington, R., 2003. Ecologically sustainable water management: managing river flows for ecological integrity. Ecol. Appl. 13, 206-224.

Ridgeway, G., 2006. GBM: Generalized Boosted Regression Models. R package Version 1.6-3.

SAGA, 2010. System for Automated Geoscientific Analysis. Version 2.0.6. SAGA User Group Association. Boston.

Schapire, R., 2003. The boosting approach to machine learning - an overview. In: Denison, D.D., Hansen, M.H., Holmes, C., Mallick, B., Yu, B. (Eds.), MSRI Workshop on Nonlinear Estimation and Classification, 2003. Springer, New York

Schreiber, A., Engelhorn, R., 1998. Population genetics of a cyclostome species pair river lamprey (Lampetra fluviatilis L.) and brook lamprey (Lampetra planeri Bloch). J. Zool. Syst. Evol. Res. 36, 85-99.

Snelder, T.H., Lamouroux, N., 2010. Co-variation of fish assemblages, flow regimes and other habitat factors in French rivers. Freshwater Biol. 55, 881-892.

Soulé, M.E., 1987. Viable Populations for Conservation. Cambridge University Press, Cambridge.

SRTM, 2010. Shuttle Radar Topography Mission. US Geological Survey. US Department of the Interior.

Vannote, R.L., Minshall, G.W., Cummins, K.W., Sedell, J.R., Cushing, C.E., 1980. The river continuum concept. Can. J. Fish. Aquat. Sci. 37, 130-137.

Wilson, K.A., Westphal, M.I., Possingham, H.P., Elith, J., 2004. Sensitivity of conservation planning to different approaches to using predicted species distribution data. Biol. Conserv. 122, 99-112.

Young, R.J., Houston, K.A., Weise, J.G., Kelso, J.R.M., 1990. The effect of environmental variables on the population dynamics of sea lamprey, Petromyzon marinus. Canadian Technical Report of Fisheries and Aquatic Sciences 1736, 33 pp.

Zanandrea, G., 1959. Speciation among lampreys. Nature 184, 380. 